\title{
Antiganglioside antibodies in Guillain-Barré syndrome after a recent cytomegalovirus infection
}

\author{
Azadeh Khalili-Shirazi, Norman Gregson, Ian Gray, Jeremy Rees, John Winer, \\ Richard Hughes
}

\begin{abstract}
Objective-To study the association between anti-ganglioside antibody responses and Guillan-Barré syndrome (GBS) after a recent cytomegalovirus (CMV) infection.

Methods-Enzyme linked immunosorbant assay (ELISA) was undertaken on serum samples from 14 patients with GBS with recent cytomegalovirus (CMV) infection (CMV+GBS) and 12 without (CMVGBS), 17 patients with other neurological diseases (OND), 11 patients with a recent CMV infection but without neurological involvement, 11 patients with recent Epstein-Barr virus (EBV) infection but without neurological involvement, and 20 normal control (NC) subjects.

Results-IgM antibodies were found at 1:100 serum dilution to gangliosides GM2 (six of 14 patients), GM1 (four of 14), GD1a (three of 14) and GD1b (two of 14) in the serum samples of the CMV+GBS patients, but not in those of any of the CMV-GBS patients. IgM antibodies were also found to gangliosides GM1, GD1a, and GD1b in one of 11 OND patients, to ganglioside GM1 in one of 11 non- neurological CMV patients, and to ganglioside GD1b in one of 20 NC subjects. Some patients with EBV infection had IgM antibodies to gangliosides GM1 (five of 11), GM2 (three of 11), and GD1a (two of 11). However, the antibodies to ganglioside GM2 had a low titre, none being positive at $1: 200$ dilution, whereas five of the CMV+GBS serum samples remained positive at this dilution.

Conclusion-Antibodies to ganglioside GM2 are often associated with GBS after CMV infection, but their relevance is not known. It is unlikely that CMV infection and anti-ganglioside GM2 antibodies are solely responsible and an additional factor is required to elicit GBS.
\end{abstract}

(F Neurol Neurosurg Psychiatry 1999;66:376-379)

Keywords: ganglioside GM2; cytomegalovirus; GuillanBarré syndrome

Guillain-Barré syndrome (GBS) is an acute

peripheral neuropathy, characteristically taking the form of an acute inflammatory demyelinating polyradiculoneuropathy. The favoured hypothesis is that the immune response to certain infective agents in some people may trigger cross reactive immunity, with initially one or more myelin or axonal antigens leading to an autoimmune attack on the nerve tissue. Antiglycolipid antibodies have often been found in affected patients. ${ }^{12}$ A preceding CMV infection with high titres of $\operatorname{IgM}$ antibody has been implicated in $10 \%-15 \%$ of the patients with GBS. ${ }^{34}$ Recent reports, some contradictory, have suggested raised concentrations of antibodies to ganglioside GM2 in patients with GBS after cytomegalovirus (CMV) infection. ${ }^{5-8}$ We have studied serum samples from patients with GBS after CMV infection and appropriate controls to investigate this relation further.

\section{Materials and methods}

PATIENTS

All available pretreatment serum samples from two series of patients with GBS, ${ }^{39}$ which had been stored at $-70^{\circ} \mathrm{C}$ for $2-12$ years, were tested for IgM antibodies to CMV. There were 26 such GBS samples, 14 from CMV+GBS patients (five male and nine female, mean age 29.8 (SD 17.2) years) and 12 CMV-GBS patients (seven male and five female, mean age 33.3 (SD 21.6) years). There were 17 OND patients (10 female and seven male, mean age 53 (SD 19) years) with the following diagnoses: motor neuron disease (seven), hereditary, toxic, or idiopathic axonal neuropathy (six), IgM paraproteinaemic neuropathy (two), epilepsy (one), and idiopathic spinocerebellar degeneration (one). Non-neurological control serum samples were from three groups: 11 patients (six female, five male, mean age 34 (SD 19) years) with recent CMV infection but no neurological disease (CMV group); 11 patients (three female, eight male, mean age 25.5 (SD 5.9) years) with EBV infection, but no neurological disease (EBV group), and 20 normal healthy control (NC) subjects (14 female, six male, mean age 47.1 (SD 17.5) years). For patients with GBS, maximum disability was scored on a scale from $0=$ normal, $1=$ minor symptoms or signs, $2=$ unable to run, $3=$ unable to walk unaided, $4=$ chair or bed bound, $5=$ ventilated. Sensory grades were scored as $0=$ normal, $1=$ symptoms but no signs, and in revised form

17 April 1998

Accepted 15 June 1998 
Clinical details and the ELISA results of the serum samples of the GBS patients, with (CMV+GBS) and without (CMV-GBS) a recent CMV infection

\begin{tabular}{|c|c|c|c|c|c|c|c|c|c|c|}
\hline $\begin{array}{l}\text { Patient } \\
\text { group }\end{array}$ & Age & Sex & $\begin{array}{l}\text { Preceding } \\
\text { events }\end{array}$ & $\begin{array}{l}\text { Days } \\
\text { from } \\
\text { onset }\end{array}$ & $\begin{array}{l}\text { Disability } \\
\text { grade at } \\
\text { sample date }\end{array}$ & $\begin{array}{l}\text { Worst } \\
\text { sensory } \\
\text { grade }\end{array}$ & $\begin{array}{l}\operatorname{IgM} \\
a n t i-G M 1 \\
a b\end{array}$ & $\begin{array}{l}\operatorname{Ig} M \\
\text { anti-GM2 } \\
a b\end{array}$ & $\begin{array}{l}\operatorname{IgM} \\
a n t i-G D 1 a \\
a b\end{array}$ & $\begin{array}{l}\operatorname{Ig} M \\
a n t i-G D 1 b \\
a b\end{array}$ \\
\hline \multicolumn{11}{|l|}{ CMV+GBS: } \\
\hline 1 & 22 & $M$ & URTI & 7 & 5 & 1 & $-(-)$ & $+(+)$ & $-(-)$ & $-(-)$ \\
\hline 2 & 31 & $\mathrm{~F}$ & URTI & 9 & 5 & 3 & $\pm(-)$ & $+(+)$ & $\mathrm{w}(-)$ & $-(-)$ \\
\hline 3 & 15 & $\mathrm{~F}$ & URTI & 7 & 5 & 2 & - & - & - & - \\
\hline 4 & 21 & $\mathrm{~F}$ & None & 18 & 2 & 1 & $-(-)$ & $-(+)$ & $-(-)$ & $-(-)$ \\
\hline 5 & 26 & $\mathrm{M}$ & None & 14 & 4 & 2 & $-(-)$ & $+(+)$ & $\mathrm{w}(+)$ & $-(-)$ \\
\hline 6 & 29 & $M$ & Flu vac & 8 & 4 & 3 & $+(+)$ & $+(+)$ & $-(-)$ & $+(\mathrm{w})$ \\
\hline 7 & 26 & M & URTI & 14 & 4 & 1 & $\pm(-)$ & $-(-)$ & $\mathrm{w}(-)$ & $-(-)$ \\
\hline 8 & 71 & $M$ & URTI & 4 & 4 & 1 & - & - & - & - \\
\hline 9 & 17 & $\mathrm{~F}$ & URTI & 12 & 4 & 1 & $\pm(+)$ & $+(+)$ & $-(-)$ & $-(-)$ \\
\hline 10 & 48 & $\mathrm{~F}$ & Operation & 8 & 5 & 1 & $\pm(+)$ & $-(-)$ & $-(-)$ & $-(-)$ \\
\hline 11 & 58 & $\mathrm{~F}$ & URTI & 12 & 5 & 3 & $-(-)$ & $-(-)$ & $-(-)$ & $-(-)$ \\
\hline 12 & 13 & $\mathrm{~F}$ & None & 14 & 4 & 1 & $+(+)$ & $+(+)$ & $+(+)$ & $+(+)$ \\
\hline 13 & 19 & $\mathrm{~F}$ & URTI & 9 & 2 & 1 & $-(-)$ & $-(-)$ & $+(+)$ & $-(-)$ \\
\hline 14 & 21 & $\mathrm{~F}$ & None & 8 & 5 & 1 & - & - & - & - \\
\hline $\mathrm{n}=14$ & $30(17)$ & $5 \mathrm{M}, 9 \mathrm{~F}$ & & $10(4)$ & $4(1)$ & $2(1)$ & 4 & 6 & 3 & 2 \\
\hline $\begin{array}{l}\mathrm{n}=14 \\
\mathrm{n}=12\end{array}$ & $33(22)$ & $7 \mathrm{M}, 5 \mathrm{~F}$ & & $11(6)$ & $4(1)$ & $2(1)$ & 0 & 0 & 0 & 0 \\
\hline
\end{tabular}

Values ( ) in the last two rows are mean (SD).

$+=$ positive (a value greater than the NC mean+3 SD); w=weak positive, $\pm=$ border line, $(+)$ or $(-)=$ positive or negative by TLC; URTI=upper respiratory tract infection; $a b=$ antibody; vac=vaccine.

Patient 2, but none of the others, had serological evidence of a recent Campylobacter jejuni infection.

An ELISA negative serum (patient 4) gave a positive band in TLC. This might be due to a difference in the epitope specificity of the antibody, but as this result was not confirmed by both methods, it was not regarded as positive.

Patient 8, but none of the others, had positive IgG antibodies to GM1 and GD1b.

$2=$ anaesthesia or analgesia of fingers or feet, $3=$ anaesthesia or analgesia to elbows or knees or worse.

\section{ANTIBODY ASSAYS}

ELISA

Antibodies to CMV were determined by enzyme linked immunosorbent assay (ELISA) (Enzygnost Kit, Behring Diagnostics, Hounslow, Middlesex, UK) with CMV infected fibroblasts and peroxidase labelled antihuman $\operatorname{IgM}$ antibody as the detection system. We did not consider any samples as containing CMV antibodies if the optical density value was less than 0.20

Antibodies against gangliosides were detected by ELISA with the following protocol. The wells of ELISA plates (Immulon 3, Dynatech, UK) were coated with $100 \mu \mathrm{l}$ gangliosides GM1 (Sigma, Poole, UK), GM2, GD1a, or GD1b (Alexis, Nottingham, UK) at $1 \mu \mathrm{g} / \mathrm{ml}$ and cholesterol ( $5 \mu \mathrm{g} / \mathrm{ml})$ in methanol, by evaporation. After washing the plates with high ionic phosphate buffered saline (PBS), non-specific binding was blocked with $1 \%$ bovine serum albumin (BSA) fraction $\mathrm{V}$ (Sigma, Poole, UK) in PBS (100 $\mu$ l) for 2 hours at room temperature. One hundred microlitres of the test and control serum samples, appropriately diluted in $1 \%$ BSA PBS, were then incubated overnight at $4^{\circ} \mathrm{C}$. The plates were washed with PBS, and then antihuman IgG or IgM conjugated to alkaline phosphatase (Sigma, Poole, UK) $(100 \mu \mathrm{l})$ was added. The plates were further incubated for 2 hours at $4^{\circ} \mathrm{C}$ and developed by incubating for 1 hour at $37^{\circ} \mathrm{C}$, with $p$-nitrophenol phosphate substrate tablets (Sigma) $(100 \mu \mathrm{l})$. The absorbance was read at $405 \mathrm{~nm}$. Serum samples were tested in triplicate and considered positive when the mean absorbance was more than 3 SD greater than the mean of the NC serum.
Thin layer chromatography with immuno-overlay All of the ganglioside ELISA positive serum samples were tested by thin layer chromatography (TLC) with immuno-overlay. A mixture of $40 \mu \mathrm{l}$ of each of the gangliosides GM1, GM2, GD1a, and GD1b, each at $1 \mathrm{mg} / \mathrm{ml}$, was resolved on $85 \mathrm{~mm}$ of aluminium backed TLC plates $(1.88 \mu \mathrm{g}$ of gangliosides $/ \mathrm{mm}$ ) (Merck, Poole, Dorset, UK) in chloroform/methanol/ $0.05 \mathrm{M} \mathrm{CaCl}_{2}$ (30:20:4, v:v:v) at $4^{\circ} \mathrm{C}$. Antibody binding was detected using standard techniques. Positive and negative control serum samples were included in each test.

\section{STATISTICAL ANALYSIS}

Multiple groups were compared with the Kruskal-Wallis analysis of variance (ANOVA) and groups of interest were compared with the normal control group with a Mann-Whitney test. Two tailed tests of significance are quoted. Differences in proportions were tested with Fisher's exact test.

\section{Results}

ANTI-CMV ANTIBODIES

Anti-CMV IgM antibodies were present in 14 patients with GBS and absent in 12 . There was no difference in the sex ratio, age, clinical features, delay between the collection of serum samples and the onset of GBS for the two groups (table). The mean optical density obtained for IgM anti-CMV antibody ELISA for the CMV+GBS group was 0.52 (SD 0.23) and for the CMV-GBS it was 0.03 (SD 0.05). The corresponding values for the patients with CMV infection but no neurological disease were 0.41 (SD 0.11) and for the EBV patients they were 0.07 (SD 0.10). The most frequent preceding illness in both GBS groups was an upper respiratory tract infection, which was reported by eight of 14 of the patients with GBS with CMV antibodies and four of 12 of those without. 

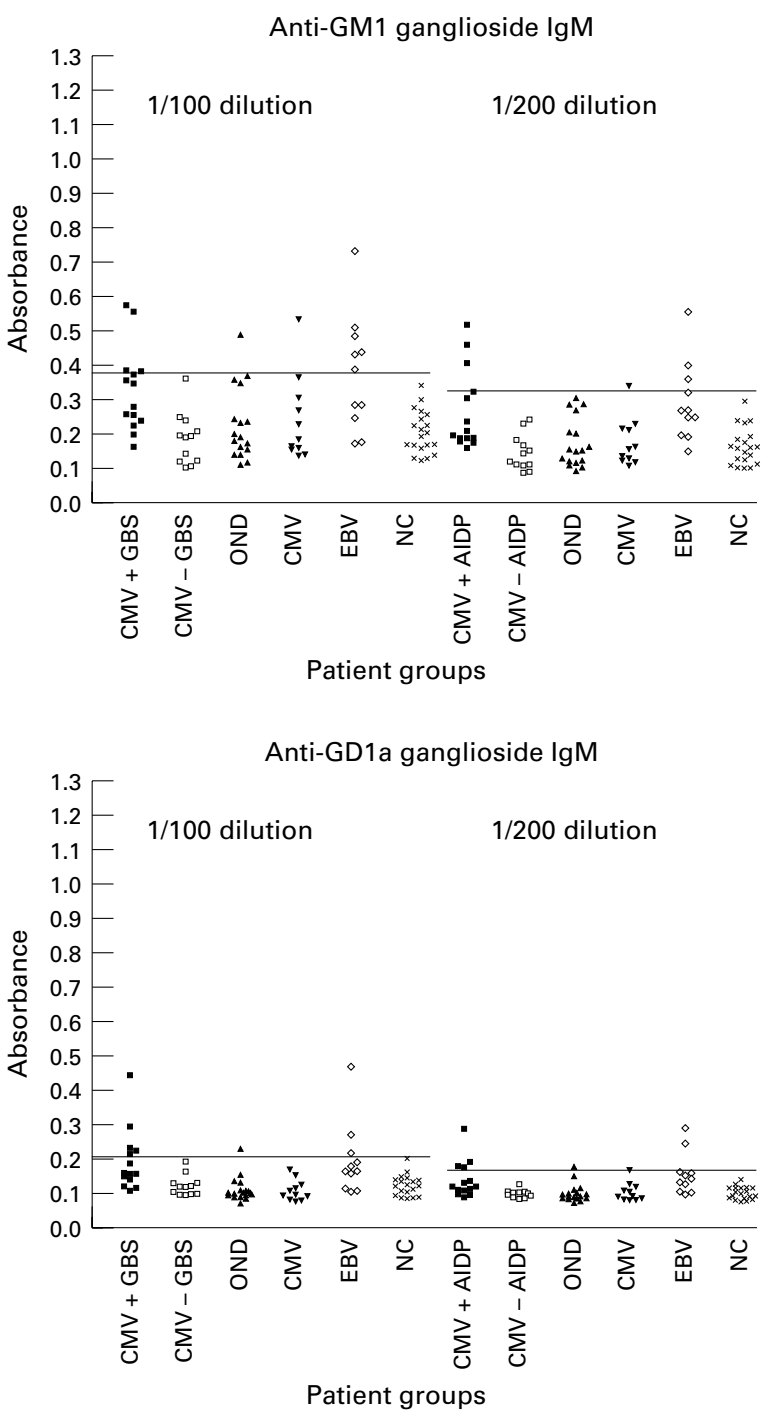

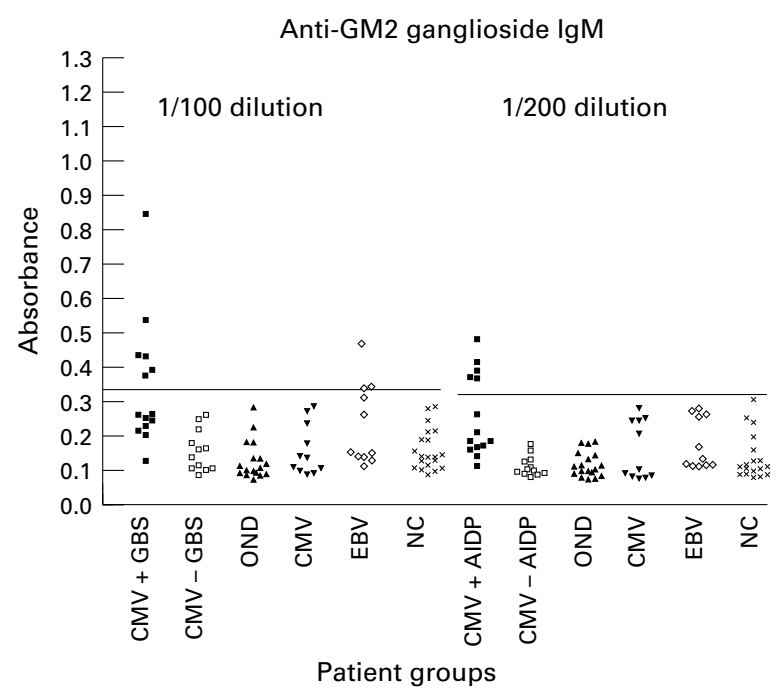

Anti-GD1b ganglioside IgM

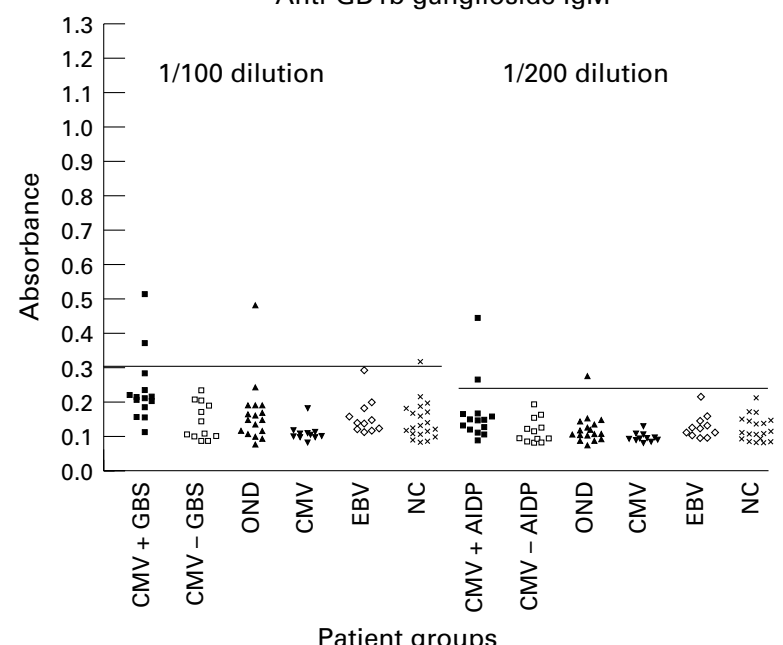

ELISA showing IgM antibodies to gangliosides GM1, GM2, GD1a, and GD1b in five groups of patients and NC subjects. The solid lines represent 3SD above the mean OD of the NC subjects. (Demonstration of the results at serum dilutions of 1:100 and 1:200, shows the presence of high titre (positive at 1:100, and 1:200) and low titre (positive at 1:100, but negative 1:200) antibodies.)

ANTI-GANGLIOSIDE ANTIBODIES

IgM antibody binding to one or more of the gangliosides was detected by ELISA in eight of 14 , and IgG antibodies in one of 14 CMV+GBS patients, but not in any of the CMV-GBS patients (table). IgM antibodies were detected against gangliosides GM1 in four of 14, GM2 in six of 14, GD1a in three of 14 , and GD1b in two of 14 patients in the $\mathrm{CMV}+\mathrm{GBS}$ group. The optical density of ganglioside GM2 in the CMV+GBS group was significantly higher than those in the CMVGBS (Mann Whitney test, $\mathrm{p}=0.0009$ ), OND $(\mathrm{p}<0.0001), \mathrm{CMV}(\mathrm{p}=0.0034)$, and NC $(p=0.0002)$ groups, but not significantly higher than those in the EBV group ( $p=0.1323)$.

Some of the antibodies were titrated, but all were tested at 1:100 and 1:200 dilutions, the results for which are shown as some low affinity antibodies become negative at 1:200 dilution. The highest anti-ganglioside GM2 IgM antibody binding occurred in patients from the CMV+GBS and the EBV groups. However, the EBV serum samples were all negative to ganglioside GM2 at 1:200 dilution, whereas five of 14 of the CMV+GBS samples were still positive at this dilution. None of the samples from the other groups contained significant concentrations of antibody to this ganglioside (figure). By contrast, IgG antibodies against gangliosides GM1 and GD1b were detected only in one of the CMV+GBS patients (results not shown). The ELISA results for individual patients showed that when antibodies were present, they were often against more than one ganglioside (table). Compared with the NC subjects, the IgM (1:100 dilution) ELISA absorbance readings of CMV+GBS patients were significantly increased against gangliosides GM1 $(p=0.001)$, GM2 $(p=0.0002)$, GD1a $(p=0.002)$ and GD1b ( $p=0.001)$. The only other group of patients with significantly raised concentrations was the EBV group, in which $\operatorname{IgM}$ anti-ganglioside binding was raised to gangliosides GM1 ( $\mathrm{p}=0.001)$ and GD1a $(\mathrm{p}=0.007)$.

TLC IMMUNO-OVERLAY

Samples were considered positive, if they were confirmed both by ELISA and TLC. Serum 
samples strongly positive by ELISA were all confirmed by TLC immuno-overlay, but some of the borderline ELISA positive samples did not bind on the TLC plates (table). In the serum from CMV+GBS patient 8, ELISA positive IgG antibody binding to gangliosides GM1 and GD1b was also confirmed by TLC immuno-overlay. The TLC immuno-overlay results for the EBV group confirmed some of the ELISA positive results for gangliosides GM1(five of six), GM2 (three of three), and GD1a (two of three). It did not detect the two borderline ELISA positive serum samples.

\section{Discussion}

This study extends previous findings on the relation between CMV infection and antiganglioside antibodies in GBS. When our findings are combined with those of previous reports, ${ }^{6-8}$ a total of 22 of $44 \mathrm{CMV}+\mathrm{GBS}$, nine of 187 CMV-GBS, two of 135 OND, seven of $71 \mathrm{CMV}$, three of $11 \mathrm{EBV}$ patients, and none of the 140 in the NC group were positive to ganglioside GM2. It becomes clear that antibodies to ganglioside GM2 are present more commonly in GBS associated with recent CMV infection, than in patients with GBS not associated with CMV ( $p=0.0001$; Fisher's exact test). Low affinity antiganglioside GM2 IgM antibodies have been reported in serum samples from normal people and may represent part of the natural antibody repertoire, ${ }^{10}$ but they have also been reported in patients with peripheral and central nervous system disease..$^{11}$

Cytomegalovirus can produce both persistent and latent infection in humans, infecting various cell types including neural and endothelial cells. There is no histological evidence of CMV infection within the nerve in GBS, and a polymerase chain reaction study did not detect CMV genome in GBS nerve biopsies. ${ }^{12}$ Cytomegalovirus is a budding virus with an envelope containing lipid, the lipids being acquired from the host cell. In addition, envelope budding viruses such as CMV may carry host derived glycolipids and render them immunogenic, ${ }^{13}$ or provide the affinity selecting antigen enhancing natural antibody production.

Ganglioside GM2 is widely distributed in extraneural tissue and might be carried by CMV during systemic infection. A significant number of CMV+GBS patients had antiganglioside GM2 IgM antibodies, but this antibody was absent from the non-neurological CMV infected control group, indicating that CMV infection alone does not commonly induce this antibody. The presence of antiganglioside GM2 antibodies in some of the neurologically normal EBV infected control group indicates that such antibodies are not necessarily associated with a neurological disease, nor restricted to a recent CMV infection. However, this antibody in the EBV patients had low titres, and may have been non-specific. The pathogenic involvement of anti-ganglioside GM2 antibodies is not known. Ganglioside GM2 is localised at the neuromuscular junction in the rat. ${ }^{14}$ The concentration of this ganglioside is increased in the plasma membrane of melanoma cell lines and neuroendocrine tumour cells and antiganglioside GM2 antibodies are cytotoxic to these cells. ${ }^{15}$ High titre antiganglioside GM2 antibodies are often reactive with other minor gangliosides such as IV4GalNAcGD1a and IV4GalNAcGM1b. ${ }^{16}$ Antibodies weakly reactive with ganglioside GM2, but strongly reactive with IV4GalNAcGD1a have been reported in a patient developing GBS after Campylobacter jejuni enteritis. ${ }^{17} \mathrm{~A}$ cross reactive shared sequence with minor gangliosides and ganglioside GM2 itself may be the relevant antigenic target in GBS. Further research into the fine specificity of antiganglioside antibodies generated after CMV and other infections is necessary to determine how these antibodies are involved in the pathogenesis of GBS.

We thank Professor J Banatvala, Department of Virology, UMDS, St Thomas's Campus, London SE1 for serum samples from CMV and EBV patients and the Special Trustees of St Thomas's Hospital, Professor HE Webb, and Action Research for financial support.

1 Ilyas AA, Mithen FA, Chen Z-W, et al. Search for antibodies to neutral glycolipids in sera of patients with Guillain-Barré syndrome. F Neurol Sci 1991;102:67-75.

2 Yuki N, Tagawa Y, Irie F, et al. Close association of GuillainBarré syndrome with antibodies to minor monosialogangliosides GM1b and GM1a. F Neuroimmunol 1997;74:30-

3 Winer JB, Hughes RAC, Anderson MJ, et al. A prospective study of acute idiopathic neuropathy. II. Antecedent events. 7 Neurol Neurosurg Psychiatry 1988;51:613-8.

4 Visser LH, Van der Meché FGA, Meulstee J, et al. Cytomegalovirus infection and Guillain-Barré syndrome: the clinical, electrophysiologic, and prognostic features. Neurology 1996;47:668-73.

5 Niwa K, Kitagawa Y, Ohta T, et al. A case of Guillain-Barré syndrome associated with anti-GM2 antibody due to cytomegalovirus infection - special reference to the effect of ganciclovir. Clin Neurol 1995;35:652-6.

6 Irie S, Saito T, Nakamura K, et al. Association of anti-GM antibodies in Guillain-Barré syndrome with acute cytomegalovirus infection. I Neuroimmunol 1996;68:19-26.

7 Jacobs BC, van Doorn PA, Groeneveld JHM, et al. Cytomegalovirus infections and anti-GM2 antibodies in GuillanBarré syndrome. I Neurol Neurosurg Psychiatry 1997;62: 641-3.

8 Yuki N, Tagawa Y. Acute cytomegalovirus infection and IgM anti-GM2 antibody. $\mathcal{F}$ Neurol Sci 1998;154:14-17

9 Rees JH, Gregson NA, Hughes RAC. Anti-ganglioside $\mathrm{GM}_{1}$ antibodies in Guillain-Barré syndrome and their relationship to Campylobacter jejuni infection. Ann Neurol 1995;38: 809-16.

10 Mizutamari RK, Wiegandt H, Nores GA. Characterisation of anti-ganglioside antibodies present in normal human of anti-ganglioside antibodies present in
plasma. $\mathcal{F}$ Neuroimmunol 1994;50:215-20.

11 Gregson NA, Jones D, Willison HJ. Antibodies against GM1 and other gangliosides in patients with motor neuron syndromes. New evidence in $M N D / A L S$ research. London: Smith-Gordon, 1991:197-208.

12 Hughes RAC, Atkinson P, Coates P, et al. Sural nerve biopsies in Guillain-Barré syndrome: axonal degeneration and macrophage-mediated demyelination and absence of cytomegalovirus genome. Muscle Nerve 1992;15:568-75.

13 Webb HE. Anti-glycolipid immunity. Neuropathogenic viruses and immunity. New York: Plenum Press, 1992:277-302.

14 Scott LJC, Bacou F, Sanes F. A synapse-specific carbohydrate at the neuromuscular junction: association with both acetylcholinesterase and a glycolipid. 7 Neurol Sci 1988;8: 932-944.

15 Ritter G, Fortunato SR, Cohen L, et al. Induction of antibodies reactive with GM2 ganglioside after immunisation with lipopolysaccharides from Campylobacter jejuni. Int $\mathcal{F}$ Cancer 1996;66:184-90.

16 Ilyas AA, Li S-C, Chou DKH, et al. Ganglioside G(M2), IV4GalNAcG(M1b), and IV4GalNAcG(D1a) as antigens for monoclonal immunoglobulin $\mathrm{M}$ in neuropathy associated with gammapathy. F Biol Chem 1988;263:4369-73.

17 Kusunoki S, Chiba A, Kon K, et al. N-acetylgalactosamine GD1a is a target molecule for serum antibody in GuillainBarré syndrome. Ann Neurol 1994;35:570-6. 